\title{
THE USAGE OF ANIMAL AND VEGETABLE ORIGIN RAW MATERIALS COMBINATORICS IN MEAT PRODUCTS OF "HALAL" CATEGORY DEVELOPMENT
}

\author{
${ }^{1}$ Ivan F. Gorlov, ${ }^{2}$ Oksana B. Gelunova, \\ ${ }^{3}$ Tatiana M. Giro and ${ }^{4}$ Ekaterina P. Mirzayanova \\ ${ }^{1}$ Volga Region Research Institute of Manufacture and Processing of Meat-and-Milk Production, \\ 400131, Rokossovskogo Street, 6, Volgograd, Russia \\ ${ }^{2}$ Volgograd State Technical University, 400005, Lenin Avenue, 28, Volgograd, Russia \\ ${ }^{3}$ Volgograd State Technical University, 400005, Lenin Avenue, 28, Volgograd, Russia \\ ${ }^{4}$ Saratov State Agrarian University Named After N.I. Vavilov, 410012, Teatralnaya Square, 1, Saratov, Russia
}

Received 2014-05-26; Revised 2014-06-11; Accepted 2014-08-27

\begin{abstract}
Integrated researches aimed to develop technologies and recipes for meat products of "Halal" category using seed fat and Milk Protein-Carbohydrate Concentrate (MPCC) represent a new generation of scientific and practical interest. In this connection, the authors propose technologies and recipes for meat products of "Halal" category, designed on the basis of rational combinatorics of animal and vegetable origin raw materials, that let us to expand the range of halal meat products and to develop cost-effective technologies. The results of the research have provided expanding the range of functional meat products, including Halal products for muslims, that meet the quality standards of the finished product in the category «Halal». Practical feasibility of using a vegetable fats complex and Milk Protein-Carbohydrate Concentrate (MPCC) «Lactobel-ED» in sausage production has been found. The levels of adding to the formula have been proved. Thermodenaturation of milk and whey proteins during thickening and drying of "Lactobel-ED" increases the availability of peptide chains and ionized amino acid residues. Solubility study showed that the concentrate is highly soluble in aqueous solutions, but this has a high dispersion degree, which increases the overall adsorption surface. Analysis of the results of structural and mechanical changes in the characteristics of minced model systems indicates a decline in YV of prototypes with sunflower oil on average 99.5 Pa.
\end{abstract}

Keywords: Meat Products, Halal Category, Combinatorics

\section{INTRODUCTION}

The most urgent problems in the nutrition of Russian population are protein deficiency, lack of micronutrients (vitamins, minerals, polyunsaturated fatty acids), imbalance of ration according the nutrients and energy (Zhuravskaya et al., 1985).

Russian population consists of a large number of people preaching Islam, Judaism and other religions.
Islam considers the term "Halal" usually as a meat of animals whose can be eaten without violating dietary restrictions (the food forbidden for Muslims) (Borisenco and Borisenco, 1998).

In a market economy, it is important to get not only a product that meets the basic canons of halal production, but also being competitive, providing cost-effectiveness during its introduction into the production process. It should be noted that the interest of enterprises in the 400131, Rokossovskogo Street, 6, Volgograd, Russia 
halal production is high enough, because their cost is much higher than the cost of products developed in the traditional way (Shahidi, 2005).

In today's global community (Potter, 1995), "Halal" ceased to be a purely religious issue, having been extended to the sphere of business and trade. It becomes a global symbol as a guarantee of quality and lifestyle choices (Potter, 1995).

The Russian market of halal products is very attractive to manufacturers, as 20 million of its citizens are followers of Islam. Consequently, the number of halal products manufactured in Russia has recently increased (Lisitcin et al., 2008). Some manufacturers consider this as an additional income and others-as a surmounting the crisis, because halal products are always in demand.

In this connection, integrated researches aimed to develop technologies and recipes for meat products of "Halal" category using seed fat and Milk ProteinCarbohydrate Concentrate (MPCC) represent a new generation of scientific and practical interest.

\section{MATERIALS AND METHODS}

Subjects of research included soy protein concentrate "Maicon S 110" made in Germany; soy isolates "Linepro 90" made in China; milky-vegetable proteincarbohydrate preparations "Belcon-Alev I» and «BelconAlev II» (manufacturer firm “Alev”, Moscow), milk protein-carbohydrate concentrates "Lactobel" and "Lactobel-ED"; refined deodorized frozen out sunflower oil (GOST R 52465-2005), emulsions based on milk protein-carbohydrate concentrate "Lactobel-ED" with sunflower oil, simulative stuffing modeling system with protein-fat emulsion based on milk protein-carbohydrate concentrate "Lactobel-ED" and sunflower oil, cooked sausage "Mutton choice sausage" PTS 10 RSFSR 939-91.

Mercury content was determined according to GOST 26927-86.

Arsenic was determined according to GOST 26930-86.

Quantitative chemical analysis of food products and raw materials samples for the content of toxic elements was conducted according to GOST 51301-99.

Determination of Water Absorbing Capacity (WAC) and Grease Absorbing Capacity (GAC) of protein products conducted according to methods of (Antipova et al., 2001).

Determining the emulsifying ability of proteinaceous products conducted according to methods of (Inklaar and Fourtuin 1969).
Determination of emulsifying ability of minced systems conducted according to Antipova et al. (2001).

Defining the stability of emulsion conducted by heating the emulsion at a temperature of 80 degrees for 30 minutes and cooling with water for $15 \mathrm{~min}$. Then 4 centrifugal test-tube for $50 \mathrm{~cm}^{3}$ were filled by this emulsion and centrifugated at a rotational speed of 500 $\mathrm{s}^{-1}$ for $5 \mathrm{~min}$. Next, we determined the volume of emulsified layer (Antipova et al., 2001).

The stability of emulsion (\%):

$$
S E=\frac{V_{1}}{V_{2}} \cdot 100
$$

$V_{1}=$ Volume of emulsified oil, $\mathrm{cm}^{3}$

$V=$ Total volume of emulsion, $\mathrm{cm}^{3}$

Determination of amino acid composition of the protein preparations and meat products was held by ionexchange chromatography using an automatic amino acid analyzer AAA 400 GOST 13496.21-87 after prehydrolysis of test portions.

Determination of water mass content in model minced systems was held by thermogravimetric drying the test portions to a constant weight at $103 \pm 2{ }^{\circ} \mathrm{C}$ according to GOST 24908-84 (Antipova et al., 2001).

Determination of the hydrogen ions concentration was carried out by the potentiometric method using a $\mathrm{pH}$ meters "pH-125", "pH-150", "pH-340" with a glass electrode ESL-15-11 and a silver chloride electrode EVL-1M4 according to GOST 26781-85.

Determination of water-binding capacity in model minced systems was held by pressing according to $\mathrm{R}$. Grauand and R. Hamm method modified by V. Volovinskaya and B. Kelman (Zhuravskaya et al., 1985).

Determination of Water-Holding Capacity in protein preparations (WHC) technique developed by Moscow State University of Food Production. A test portion about $2 \mathrm{~g}$ was hydrated in water in a ratio 1:5 for 1 hour, then placed in a thermostat glasses with temperatures $74-76^{\circ} \mathrm{C}$ for $15 \mathrm{~min}$. Then the content was transferred to jars and centrifuged for $15 \mathrm{~min}$ at $1000 \mathrm{rev} / \mathrm{min}$ for the separation of the unbound moisture and then the content was weighed. Waterholding capacity is calculated from the formula:

$$
W H C=\left(M_{\mathrm{h}}-M_{\mathrm{d}}\right) / M_{\mathrm{d}}
$$

$M_{h}=$ Weight of hydrated preparation

$M_{d}=$ Weight of dry preparation 
Determination of the Yield Value (YV) is held on a Geppler rheoviscosimeter whose operation is based on measuring the amount of the certain mass cone displacement in the test mincemeat for a fixed time.

Determination of the penetration degree was defined using a Geppler rheoviscosimeter by millimeters needle dive into the finished product (Gorbatov, 1979).

Determination of the final product yield was defined by a weight method as the ratio of the product after heat treatment weight to the weight of unsalted raw materials.

Determination of the organoleptic characteristics was carried out by five-grade system according to GOST 13979.15-68.

\section{RESULTS}

In mutton grown in the Saratov region was discovered the copper content in 24 times, lead in 12.5 times, zinc in 16 times less than that allowed by the regulatory documentation; such toxic elements such as mercury, arsenic, cadmium and pesticides were detected. This shows the advantages of using mutton grown in the Volga region as the main raw material in the manufacturing of meat products of "Halal" category.

In the North Caucasus Federal University under the leadership of the member of the Academy Agricultural Sciences, prof. A.G. Hramtsov was developed an innovative technology for production of milk proteincarbohydrate concentrate "Lactobel-ED" produced from milk whey demineralized by electrodialysis and skim milk. The composition "Lactobel-ED" includes milk proteins, lactose, milk salt, lactulose.

Analysis of experimental data (Table 1) investigating the chemical composition of protein preparations suggests that dry protein preparations are valuable raw materials for the production of sausages. Protein content in vegetable preparations significantly superior preparations based on recycling of milk. Thus, the protein content of "Micon 110-S", "Linepro-90" is 90.692.3\%, "Belcon-Alev", "ED-Lactobel "-23.5-49.0\%. Indicator fat content varies in vegetable preparations from 0.2 to $0.5 \%$, in animals- $1.0-5.0 \%$ respectively.

In order for an adequate choice of the emulsifier for replacement an animal fat to vegetable were investigated functional and technological properties of protein preparations and their comparative analysis. As a subject of research were selected the following preparations: Soy protein concentrate "Maicon S 110" (Germany), soy protein isolate "Laynpro 90" (China); milky vegetable protein-carbohydrate preparations "Belcon-Alev I» and « Belcon-Alev II» (“Alev", Moscow), milk protein- carbohydrate concentrates "Lactobel" and "LactobelED” (joint development specialists SKFU headed by Academician of the RAAS, Prof. A.G. Hramtsov).

It was experimentally established that the investigated protein vegetable preparations have sufficiently a high level of Water Absorption Capacity (WAC)-for soy protein concentrate "Maicon S 110"$119.1 \%$, for soy isolate "Linepro 90"-117.2\% and Grease Absorbent Capacity (GAC)-for isolate and soy concentrate this figure roughly at the same level$126.2 \%$ and $125.6 \%$ (Fig. 1).

To investigate the emulsifying properties of protein preparations we used one percent solutions of the protein and each protein preparation was prepared by a series of emulsions with a fat phase containing from $10 \%$ to $80 \%$. Values of emulsifying capacity of soy protein concentrate "Maicon $110 \mathrm{~S}$ " and soy isolate "Linepro $90 "$ are almost at the same level about 235,4 and 233.1 grams of fat per 1 gram of protein, respectively.

The composition of milk-vegetable protein and carbohydrate preparations "Belcon Alev I» and «Belcon Alev II» includes whey protein concentrate obtained by ultrafiltration, skim milk, soy-based food "soy milk". Values of WAC of these preparations are $115.3 \%$ and $103.7 \%$, respectively, that are significantly lower than values of this index in milk protein-carbohydrate concentrates "Lactobel" and "Lactobel-ED"-172.0\% and $130.6 \%$. GAC of milk protein-carbohydrate concentrates "Lactobel" and "Lactobel-ED" are at the same level (140.0\% and $137.8 \%$ ), slightly below the figures in the protein-carbohydrate preparations "Belcon Alev I»$121,6 \%$ and "Belcon Alev II»-127,5\%.

Among the considered protein products of animal origin the highest rate of emulsifying capacity was seen in protein preparations "Lactobel-ED" (150.0 grams of fat per 1 gram of protein) and "Belcon Alev II" (152,1 grams of fat per 1 gram of protein).

Values of considered indicators of vegetable protein preparations (WAC, GAC) are higher than that ones in the protein products of animal origin. Due to the additional processing of concentrates and isolates during their production.

Studies of amino acid composition of soy protein concentrate "Maicon S 110" and milk proteincarbohydrate concentrate "Lactobel-ED" showed that the full animal proteins are far superior nutritionally than vegetable ones, since they are better balanced according to an amino acid composition and meet the needs of the human body in the essential amino acids. 


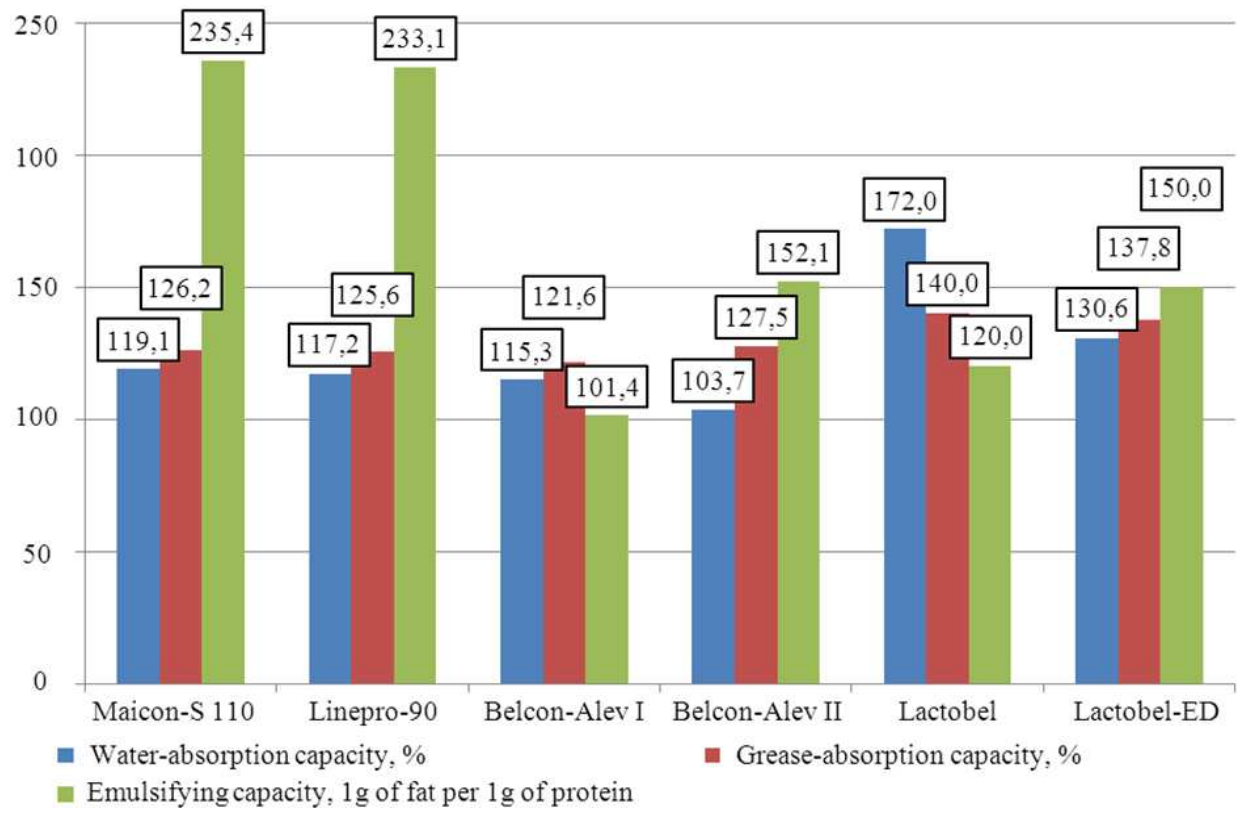

Fig. 1. Water-absorption and grease absorbent capacity of protein compounds

Table 1. Chemical composition of protein compounds

\begin{tabular}{|c|c|c|c|c|c|}
\hline \multirow[b]{2}{*}{ Name of protein compound } & \multicolumn{5}{|c|}{ Content, \% } \\
\hline & Moisture & Fat & Protein & Carbohydrates & Ashes \\
\hline Maicon-S 110 & 7,3 & 0,5 & 92,3 & - & 0,2 \\
\hline Linepro-90* & 6,0 & 0,2 & 90,6 & - & 5,8 \\
\hline Belcon-alev I ** & 6,7 & 4,0 & 49,0 & 35,0 & 4,5 \\
\hline Belcon-alev II $* *$ & 5,7 & 5,0 & 37,0 & 47,6 & 4,7 \\
\hline Lactobel $* * *$ & 5,5 & 1,5 & 27,7 & 60,8 & 11,8 \\
\hline Lactobel-ED & 5,9 & 1,0 & 23,5 & 59,5 & 9,5 \\
\hline
\end{tabular}

* -joint research with Cand. Engineering Sc. Marchenko V. V; ** -joint research with Cand. Engineering Sc. Statsenko E. N; *** -research of Cand. Engineering Sc. Barybina L. I

Was found that the content of deficient amino acids such as lysine, leucine, isoleucine, methionine in milk protein-carbohydrate concentrate "Lactobel-ED" is higher than the standard provided by FAO and soy protein concentrate "Maicon S 110" and is about on par with beef premium. It is known that the digestibility of animal proteins lies in the range $78-90 \%$, whereas the vegetable proteins are only $54-75 \%$. Thus the increased amount of sulfur containing amino acids-cystine and methionine comparing with the standard FAO/WHO and concentrate "Maicon S 110" will improve the amino acid composition of the new types of meat.

Emulsifying properties of protein concentrate "Lactobel-ED" were studied in systems "fat phase" (sunflower oil)-dispersion of "Lactobel-ED" and "fat phase" (coconut oil)-dispersion of "Lactobel-ED".
For study the emulsifying properties of protein concentrate "Lactobel-ED" was used $1 \%$ protein solution. Stability of emulsions was assessed after the heat treatment. The results of the experiment are shown in Fig. 2.

Studies of sunflower oil as the fatty phase in determining the ability of emulsifying "Lactobel-ED" showed that the introduction of up to $60 \%$ fat phase the concentrate "Lactobel-ED" formed stable emulsions. After introduction of $60 \%$ fat phase the emulsifying ability of the concentrate was $150 \mathrm{~g}$ of fat per 1 gram of protein. Resilience of stabilized emulsions increases with increasing concentration of the fat phase in the system, achieving the highest values for initial fraction of fat in the system to $60 \%$ for sunflower oil. 
For study an effect of phosphate on emulsifying ability of concentrate was used phosphate mark "UN Kuravis" Company "THERMPHOS" (UK). Phosphate brand "Kuravis UN" is a mixture of sodium triphosphate (E451i) and sodium pyrophosphate (E450i) with $\mathrm{pH}$ of its 1 percent solution-8.2. Phosphate concentration was varied between 0.5 and $1 \%$.

Was set a positive impact of phosphates on emulsifying ability of the concentrate "Lactobel-ED" in systems with coconut and sunflower oils. This may be due to an increase of $\mathrm{pH}$ and formation of more stable adsorption layers at the interface. Proportion of bound fat reached $233.3 \mathrm{~g}$ of fat per 1 gram of protein at the initial volume fraction of $70 \%$ fat phase, represented by sunflower oil. An increase of emulsifying ability systems studied in the presence of one percent sodium phosphate.

According to the results of studies conducted earlier was found that the addition of salt into the "fat phase" (sunflower oil)-dispersion "Lactobel-ED" adversely affects on the emulsifying ability of the concentrate. Based on these studies it is proposed to prepare a protein-fat emulsion without added salt and enter them at the final stage of preparing the meat, when the concentration of sodium chloride in it will decrease due to the introduction of water.

Prototypes of model systems were made from minced lamb of 1 grade. As a check sample was used boiled sausage "Mutton choice sausage".

Studies have shown that with increasing levels of adding the concentrate into emulsions physic-chemical characteristics of model mince systems of raw samples compared to the check sample were improved. It should be noted an increase in Water-Binding Capacity (WBC) in model systems minced of raw sample cooked sausages by $2 \%$ due to $\mathrm{pH}$ shift to higher values of myofibrillar proteins from isoelectric point and increasing their solubility and hydration level.

Research of emulsifying ability in minced systems revealed that the maximum level of emulsifying capacity for prototypes with sunflower oil is $25.50 \%$ with $93.68 \%$ of emulsion stability.

According to the data (Table 2), in the heat-treated samples there is a trend of increasing $\mathrm{pH}, \mathrm{WBC}$ with increasing levels of the addition protein preparation "Lactobel-ED" in the form of emulsions into the samples.

Based on the experimental data was carried out the optimization the recipes of sausage products "Halal" category by the program "Optimix", developed specifically for this purpose. Solution of this problem was held by a computer using the simplex-method, which according to certain boundary conditions makes it possible to obtain a list of recipes maximally satisfying the requirements.

This multivariate principle of design meat recipes is based on increasing content of polyunsaturated fatty acids with the exception of cholesterol raw materials; increase bioavailability, preventing oxidative and microbial spoilage, increase shelf life by storing of natural antioxidants, improving the nutritional value of the product by introducing prescription composition milk protein-carbohydrate concentrate "Lactobel-ED", which gives high functional and technological properties.

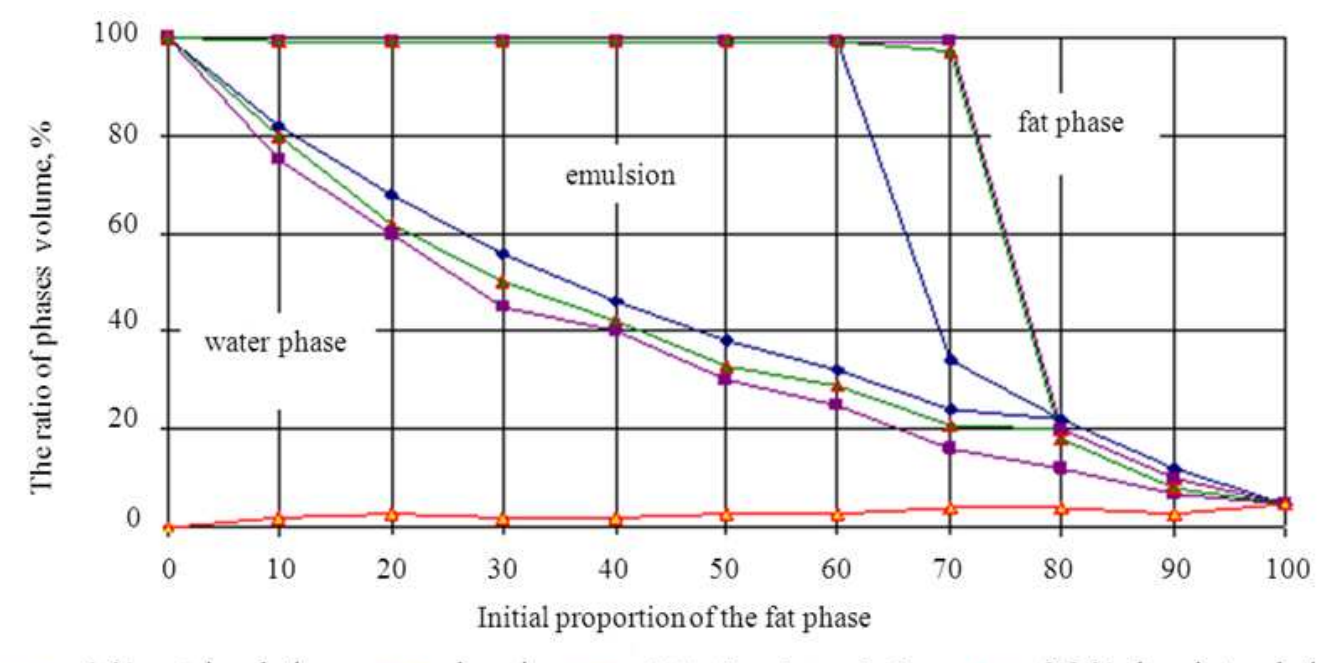

$\rightarrow 1-\%$ protein solution $\rightarrow$ deposit $\rightarrow 1-\%$ phosphate solution $\rightarrow 0,5-\%$ phosphate solution

Fig. 2. The ratio of phases volume in system "fat phase (sunflower oil)-dispersion "Lactobel-ED" as function of phosphate concentration 
Ivan F. Gorlov et al. / American Journal of Agricultural and Biological Sciences 9 (4): 474-481, 2014

Table 2. Functionally-technological and structural-mechanical properties of heat-treated samples of model mince systems such as cooked sausages

\begin{tabular}{|c|c|c|c|c|c|c|c|c|}
\hline \multirow[b]{3}{*}{ Characteristics } & \multicolumn{8}{|l|}{ Samples } \\
\hline & \multirow[t]{2}{*}{ Control } & \multicolumn{7}{|c|}{ Control samples with sunflower oil } \\
\hline & & 1 & 2 & 3 & 4 & 5 & 6 & 7 \\
\hline Addiction level of «Lactobel-ED» & 2,0 & 2,5 & 3,0 & 3,5 & 4,0 & 4,5 & 5,0 & \\
\hline $\mathrm{pH}$, un & 5,99 & 6,05 & 6,06 & 6,07 & 6,08 & 6,13 & 6,14 & 6,16 \\
\hline Moisture contents, $\%$ & 62,5 & 62,2 & 62,3 & 62,3 & 62,9 & 64,5 & 64,6 & 63,1 \\
\hline WBC, $\%$ to the total moisture content & 67,7 & 70,4 & 70,56 & 70,6 & 71,3 & 71,7 & 71,9 & 69,7 \\
\hline Penetration degree, $\mathrm{mm}$ & 5,4 & 6,3 & 6,1 & 6,3 & 6,4 & 6,5 & 6,6 & 6,2 \\
\hline Yield, $\%$ to the mass of raw materials & 104,8 & 106,5 & 107,2 & 107,5 & 109,3 & 110,7 & 112,2 & 113,6 \\
\hline Organoleptic estimate, bal. & 4,4 & 4,6 & 4,8 & 4,8 & 4,4 & 4,7 & 4,8 & 4,5 \\
\hline
\end{tabular}

To solve the problem as an objective function was selected the ratio of protein and fat in the compositions and the cost of product. The recommended level of milk protein-carbohydrate concentrate "Lactobel-ED" in the form of emulsion is $4.5 \%$. Developed recipes and technologies for sausages category "Halal" were made by educational-research laboratory of the Department "Technology of meat and dairy products" of Saratov State Agrarian University named after N.I. Vavilov.

\section{DISCUSSION}

Functional animal proteins have, as a rule, neutral taste and smell, which distinguish them from the soy protein (Gorbatov, 1979). Therefore, working with protein preparations of animal origin is eliminated the need for modifying the taste for neutralization the characteristic "beany" odor caused by oxidation of lipids (Hunter, 2002). Milk protein-carbohydrate concentrate "Lactobel-ED" contains bifidus-factor-lactulose, which is one of the best prebiotic capable for effective restoration of intestinal microflora (Laykova and Shipulin, 2007). Furthermore, it has a number of other important properties-hepatoneuroprotection and antiendotoxic effect. It should be noted that milk proteincarbohydrate concentrate "Lactobel-ED" (PTS 9229001-79993300-2006) was developed on the basis of concentrate "Lactobel" in order to create a protein preparation with a high content of reducing sugars, as well as with the lowest mineral content (monovalent ions). On the resulting product with the brand name "Lactobel-ED" was filed an application for an invention (priority reference number 2006119751/20 (021460) from 06.06.2006). "Lactobel-ED" is an organic compound with surface-active properties. Thermodenaturation of milk and whey proteins during thickening and drying of "Lactobel-ED" increases the availability of peptide chains and ionized amino acid residues. Solubility study showed that the concentrate is highly soluble in aqueous solutions, but this has a high dispersion degree, which increases the overall adsorption surface (Hunter, 2002).

Increasing emulsifying ability of concentrate "Lactobel-ED" can be explained by the fact that the major casein fractions ( $\alpha$ [alfa], $\beta$ [beta] and $\chi$ [kappa]-casein) in solution form complexes in which individual polypeptide chains linked by carboxyl groups and phosphoric acid residues through calcium bridges (Shnackel, 1987). A large number of such complexes with calcium ions and calcium phosphate are combined to casein micelles. Complexes in micelles are in the form of oriented layers. Effect of phosphate results to the binding of calcium ions, whereby the micelle disintegrates into submicelles which consist of several casein complexes.

Removal of calcium from separate casein complexes leads to formation of a monomer having hydrophilic or hydrophobic properties. Most strong hydrophilic properties are presented by $\chi$ [kappa]casein, hydrophobic-by $\beta$ [beta]-casein. Hydrophobic surfaces bind fat, hydrophilic ones attach water dipoles (Kravchenko and Kleopina, 1964). That means that there is a process of "loosening" the protein structure, which leads to the total surface adsorption increase and consequently also to the emulsifying ability (Inklaar and Fortuin, 1969).

Analysis of the results of structural and mechanical changes in the characteristics of minced model systems indicates a decline in YV of prototypes with sunflower oil on average $99.5 \mathrm{~Pa}$. What can be explained by decreased proportion of myofibrillar proteins, but increased the tenderness and juiciness of the finished product (Hoerr, 1960). 
Tasting score of the final product showed an acceptable use of refined deodorized sunflower oil in emulsions. Sample with sunflower oil differed more delicate texture and a more intense color.

\section{CONCLUSION}

\subsection{Practical Implications}

The norms of adding the phosphate drug to the emulsions and using fats and MBUK "Lactobel-ED", that provides improving the performance attributes of the minced meat systems and the qualitative characteristics of the finished product, are substantiated.

By using the program "Optmix", the recipe of cooked and smoked sausages in the category "Halal" has been optimized.

The recipes and the sausage formulation for the category "Halal" have been developed. They have pasted evaluation test at the meat processing plant LLC "Halal" in Samara region.

Technical documentation for some sorts of sausage has been developed and approved: For the cooked sausage of the first grade "PRIMA-like" (Commodity Specification 9213-001-02067965-2009); for the semismoked sausage of the first grade «Mirzayanovskaya» (Commodity Specification 9313-001-02067965-2009).

\subsection{Practical Use of the Results}

The sorts of sausage have been certified with specifications and technical documentation, the technology has been approved by the Muftis Council of Saratov region. Manufacturers of these products get some additional profit, because the brand of "Halal" gives them a competitive advantage in the food market and halal products are always in demand. The technology provides a high-quality product for healthy nutrition with biologically safe meat. Developed recipes and technologies of the sausage category "Halal" have been applied in the training-researchproduction hall-laboratory of the Department "Technology of meat and dairy products» of Saratov State Agrarian University n.a. N.I. Vavilov".

Taking into account that the use of pork is prohibited in the recipes of category products "Halal", the development of production technologies, simulating natural bacon, is relevant. In this regard, the development of formulae and technologies of the meat category "Halal" with lamb, vegetable fat and Milk Protein-Carbohydrate Concentrate (MPCC) of new generation is of scientific and practical interest.

\subsection{Research Perspectives}

While studying the oxidation dynamics of vegetable fat and pork lard during the storage, the choice of the temperature variation range has been justified not sufficiently. It is necessary to prove that the developed sausages can be dealt with as functional products, due to their content of vegetable fats and prebiotic lactulose. In the future, a comprehensive medical and biological evaluation of new products is going to be given, a more complete and better clinical studies will be undertaken on the basis of a special hospital, with subsequent monitoring the results.

The aim of the further research is to prove that the replacement of pork lard with vegetable fats in the sausage formulae is not only full-flavored, but also will improve the functional chop properties and the quality characteristics of the products and expand the product range for particular population groups according to their nation-specific diet.

The studies of physicochemical, structural and mechanical properties of model minced sausage systems, containing emulsions based on vegetable fat and milk protein-carbohydrate concentrate "Lactobel-ED", have presented the levels of milk protein-carbohydrate concentrate use not sufficiently.

\section{ACKNOWLEDGEMENT}

The researchers acknowledge receiving support from the grant of President of Russian Federation \#SS2602.2014.4. We are responsible for all errors as well as heavy style of manuscript.

\section{REFERENCES}

Antipova, L.V., I.A. Glotov and I.A. Rogov, 2001. Research Methods of Meat and Meat Products. 1st Edn., Kolos, Moscow, pp: 376.

Borisenco, L.A. and A.A. Borisenco, 1998. Basic laws change biotechnological characteristics of raw meat within its classification groups. Meat Industry, 1: 41-45.

Gorbatov, A.V., 1979. Rheology of Meat and Dairy Products. 1st Edn., Food Industry, Moscow, ISBN10: 19800457254 , pp: 382.

Hoerr, C.W., 1960. Morphology of fats, oils and shortenings. J. Am. Oil Chem. Society, 37: 539-546. DOI: $10.1007 / \mathrm{BF} 02630522$

Hunter, J.E., 2002. Trans-fatty acids, effects and alternatives. Food Technol., 56: 140-140. 
Inklaar, P.A. and J. Fortuin, 1969. Determining the emulsifying and emulsion stabilizing capacity of protein meat additives. Food Technol., 23: 103-107.

Kravchenko, N.A. and G.V. Kleopina, 1964. Guide Chromatographic Analysis of Amino Acids on Columns. 1st Edn., Nauka, Moscow, pp: 71.

Laykova, E.P. and V.I. Shipulin, 2007. About the prospect of creating functional meat products' recipes. Proceedings of International Forum on Science, Technics and Education Problems, (TEP' 07), Earth Sciences Academy, pp: 13-14.

Lisitcin, A.B., V.P. Lushnikov, Y.V. Tatulov and T.M. Giro, 2008. Production and Processing lamb Directory Stamped UMO. 1st Edn., Nauka, Saratov, pp: 418 .
Potter, D., 1995. Positive nutrition-making it happen. Food Ingredients Europe.

Shnackel, W., 1987. Evaluation of konjas gels as fat substitutes meat "emulsion" products. Meat Sci., 53: 47-53.

Shahidi, F., 2005. Dietary Fat and Health. Bailey's Industrial Oil and Fat Products. 6th Edn., John Wiley and Sons, Hoboke, ISBN-10: 0471384607, pp: 3616.

Zhuravskaya, N.K., L.T. Alehina and L.M. Otryashenkova, 1985. Studies and Quality Assurance of Meat and its Products. 1st Edn., Agropromizdat, Moscow, pp: 296. 